\title{
Delivering intrapulmonary percussive ventilation physiotherapy with assisted autogenic drainage is associated with a lower incidence of ventilator- associated gram-negative infection
}

\author{
M Borremans', M Diltoer, J De Regt, PM Honoré, C Bruggemans, H Spapen
}

From ESICM LIVES 2015

Berlin, Germany. 3-7 October 2015

\section{Introduction}

Chest physiotherapy is frequently provided to ICU patients but its role remains questionable. Intrapulmonary percussive ventilation physiotherapy with assisted autogenic drainage (IPV-AAD) is an emerging form of chest physiotherapy designed to enhance clearance of endobronchial secretions whilst enhancing alveolar recruitment.

\section{Objectives}

To evaluate the effect of IPV-AAD on the occurrence of Gram-negative (GN) ventilator-associated tracheobronchitis (VAT) or pneumonia (VAP).

\section{Methods}

Consecutive patients admitted to a mixed medicosurgical ICU were eligible for study enrolment if they required oral intubation and mechanical ventilation for at least $48 \mathrm{~h}$. Patients who at outset presented any pulmonary infiltrate(s) were excluded. Patients were randomly assigned to receive either IPV-AAD, conventional physiotherapy (CPT) or no physiotherapy (NPT). CPT consisted of expiratory chest wall vibrations, positioning, rib-springing, aerosol therapy, and airway suctioning. The NPT group underwent mobilization, aerosol therapy and tracheobronchial aspiration. Standard institutional VAP precautions were guaranteed in all patients. IPV-AAD and CPT were performed by 2 dedicated and skilled respiratory therapists. Sessions were delivered twice daily for $20 \mathrm{~min}$ on a $24 / 7$ basis. VAT and VAP were diagnosed according to established criteria (1).
Study endpoint was clinically documented VAT or VAP plus a quantitative bacterial culture of at least $10^{6} \mathrm{CFU} /$ $\mathrm{mL}$ of a true GN pathogen from an endotracheal specimen or at least $10^{4} \mathrm{CFU} / \mathrm{mL}$ from bronchoalveolar lavage fluid. Statistical analysis used non-parametric tests for independent samples and Fisher exact test to compare treatment groups.

\section{Results}

Forty-five patients ( 24 males, 21 females) were enrolled with 15 subjects included in each study arm. IPV-AAD patients were younger $(46 \pm 17$ years) than CPT (62 \pm 18 years) and NPT (64 \pm 16 years) subjects $(\mathrm{p}=0.014$; IPV-AAD vs. CPT and NPT) but APACHE II scores were comparable between groups $(20 \pm 8,23 \pm 10$ and $21 \pm 6$ respectively for IPV-AAD, CPT and NPT subjects, $\mathrm{p}=\mathrm{NS})$. GN VAT or VAP was diagnosed in 2 patients (13\%) in the IPV-AAD group, 7 patients (47\%) in the CPT group and 7 patients (47\%) in the NPT group $(\mathrm{p}=0.10$; IPV-AAD vs. CPT and NPT). Time from start of the study till VAT/VAP diagnosis ranged from 3 to 11 days. Survival was not different between groups.

\section{Conclusions}

In this small patient cohort, adjunctive IPV-AAD tended to decrease the incidence of ventilator-associated GN infection as compared with conventional or no chest physiotherapy.

Published: 1 October 2015

University Hospital Brussels, ICU, Brussels, Belgium

\section{SpringerOpen ${ }^{\circ}$}

(c) 2015 Borremans et al.; This is an Open Access article distributed under the terms of the Creative Commons Attribution License (http://creativecommons.org/licenses/by/4.0), which permits unrestricted use, distribution, and reproduction in any medium, provided the original work is properly cited. 


\section{Reference}

1. Craven DE, and Hjalmarson KI: Ventilator-associated tracheobronchitis and pneumonia: thinking outside the box. Clin Infect Dis 2010, 51(Suppl 1): S59-S66.

doi:10.1186/2197-425X-3-S1-A443

Cite this article as: Borremans et al: Delivering intrapulmonary

percussive ventilation physiotherapy with assisted autogenic drainage

is associated with a lower incidence of ventilator-associated gram-

negative infection. Intensive Care Medicine Experimental 2015 3(Suppl 1):

A443.

\section{Submit your manuscript to a SpringerOpen ${ }^{\oplus}$} journal and benefit from:

- Convenient online submission

- Rigorous peer review

- Immediate publication on acceptance

- Open access: articles freely available online

- High visibility within the field

- Retaining the copyright to your article

Submit your next manuscript at $\gg$ springeropen.com 